\title{
Phylogeny of Falconidae and phylogeography of Peregrine Falcons
}

\section{Michael WINK}

Received:April 5, 2018 - Revised: September 26, 2018 -Accepted: December 23, 2018

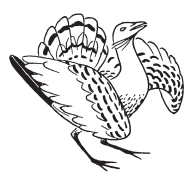

Wink, M. 2018. Phylogeny of Falconidae and phylogeography of Peregrine Falcons. - Ornis Hungarica 26(2): 27-37. DOI: 10.1515/orhu-2018-013

eny of the falcons (genus Falco), which was reconstructed on the basis of DNA sequences. Whether the 19 subspecies of the Peregrine Falcon can be identified genetically is examined in the next step. Recently, the question of Peregrine Falcon's genetics in Central Europe has become of wider interest. Which subspecies was present before the collapse of populations and which currently after various reintroduction projects? Evidence is provided, that Central Europe constitutes a (natural) hybrid zone between F. p. brookei from the Mediterranean and F. p. peregrinus of northern Europe.

Keywords: molecular phylogeny, Falconiformes, Falco, Peregrine subspecies

Összefoglalás Első lépésként áttekintjük, hol helyezkednek el a sólymok a madarak törzsfáján. Következő lépésként megvizsgáljuk a vándorsólyom filogenetikai helyzetét a sólymok (Falco nemzetség) átfogó filogenetikáján belül, DNS szekvenciák összehasonlításával. Ezt követően a vándorsólyom 19 alfajának genetikai azonosítására törekszünk, ugyanis a közép-európai populációk genetikája egyre inkább az érdeklődés középpontjába került az utóbbi időben. Kérdés, mely alfajok voltak jelen a populációk összeomlásakor, illetve melyek kerültek be a viszszatelepítési programokkal? Bizonyítékok vannak arra vonatkozóan, hogy Közép-Európa a mediterrán F. p. brookei és az észak-európai $F$. p. peregrinus alfajok természetes hibridzónája.

Kulcsszavak: molekuláris filogenetika, sólyom-alakúak, Falco, vándorsólyom alfajok

Heidelberg University, Institute of Pharmacy and Molecular Biotechnology, INF 364, D-69120 Heidelberg, Germany,e-mail:wink@uni-heidelberg.de

\section{Where are falcons in avian tree of life?}

Falcons belong to the family Falconidae, which is divided into two subfamilies Falconinae and Herpetotherinae. The subfamily Falconinae is further divided into two tribes Polyborini and Falconini. While the Polyborini are limited in their distribution to the New World, representatives of the Falconini live on all continents (del Hoyo \& Collar 2014, del Hoyo et al. 2014). Falcons have traditionally been placed in the common order Falconiformes with other birds of prey due to their appearance and lifestyle as predators (Sibley \& Monroe 1990). However, recent genomic DNA studies (Hackett et al. 2008, Jarvis et al. 2014, Prum et al. 2015) show that this classification is not correct and that similarities in appearance and behaviour are convergent characters. While Cathartidae (New World vultures), Pandionidae (Osprey), Accipitridae (eagles, buzzards, hawks, kites, harriers) and Sagittariidae (Secretarybird) have a common ancestor and are united as Accipitriformes, the falcons fall into a 
more distant grouping, which includes falcons, parrots and passerine birds (the "Eufalconimorphae" clade) (Hackett et al. 2008, Suh et al. 2011, Wink 2012, 2013, 2015, Jarvis et al. 2014, Prum et al. 2015, Kraus \& Wink 2015). Therefore, the order Falconiformes today comprises only the family Falconidae (Figure 1). In the evolution of birds, the specialisation as a predator apparently occurred repeatedly and convergently, e.g. in birds of prey (Accipitriformes sensu stricto), owls (Strigiformes) and falcons (Falconiformes). But also seagulls and skuas exhibit many elements of birds of prey in their hunting behaviour.

\section{Phylogeny of the genus Falco}

Almost 25 years ago, we started to investigate the phylogenetic relationships within birds of prey using DNA markers (Seibold et al. 1993, Wink 1995, 2000, Wink \& Ristow 2000, Wink \& Sauer-Gürth 2000, 2004, Wink et al. 1996, 2000, 2004, 2010). As marker genes, we have selected the nucleotide sequences of the mitochondrial cytochrome $b$ gene, which is very well suited for family and genus level analysis, and the nuclear gene RAG-1. The methods have been described in detail in Wink and Sauer-Gürth $(2000,2004)$ and Storch et al. (2013). Figure 2 shows a molecular phylogeny of falcons of the genus Falco with 35

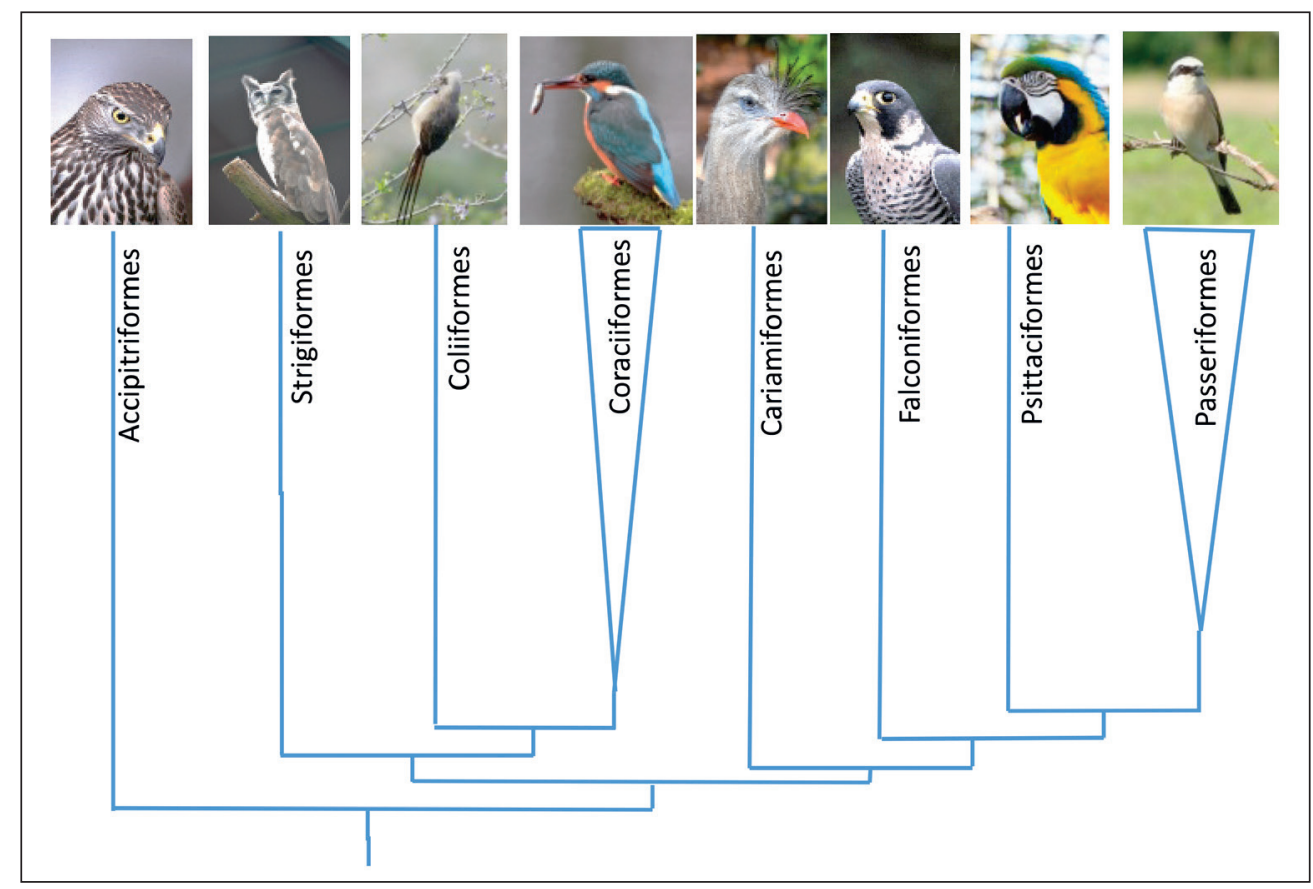

Figure 1. Position of falcons in the avian tree of life (simplified after Prum et al. 2015). The original phylogeny comprises genome sequences of 198 species (259 nuclear genes with 390000 nucleotides for each taxon). (Photos: M. Wink)

1. ábra A sólymok filogenetikai elhelyezkedése a madarak életfáján (Prum et al. 2015 nyomán leegyszerűsítve). Az eredeti filogenetikai elemzés 198 faj genom szintű szekvenciáit tartalmazza (259 nukleáris gén, fajonként 390000 nukleotiddal). (Fotók: M. Wink) 
of the 38 known falcon species (only F. moluccensis, F. rufigularis, F. severus are missing in this phylogeny), which was created on the basis of DNA sequences of the cytochrome $b$ gene. As one can easily see, most falcon species are grouped as it would have expected due to morphological characteristics (Weick 1980, del Hoyo et al. 1994). Important results are:

Three major clades are apparent in falcons (family Falconidae) (Figure 2). The subfamily Herpetotherinae at the base, followed by the tribes Polyborini and the Falconini (Figure 2). Within the tribe Falconini Falconets and Pygmy Falcons of the genera Polihierax and Microhierax cluster at the tree base and as a sister group to the monophyletic genus Falco. Within the genus Falco, some monophyletic groups are clearly identified.

The Peregrine Falcon ( $F$. peregrinus) is differentiated into various subspecies, which are genetically only slightly distinct; i. e. the branch lengths in the phylogram are very short. F. pelegrinoides, formerly separated as Barbary Falcon, is clearly a Peregrine Falcon and should therefore be considered as a subspecies with $F$. peregrinus. The Taita Falcon (F. fasciinucha) from Africa is very closely related to the Peregrine Falcon (Bell et al. 2014) and might be regarded as a subspecies of the Peregrine Falcon rather than an independent species.

The lineage of Hierofalco, which comprise F. rusticolus, F. cherrug, F. biarmicus, and $F$. jugger, form the sister group to the Peregrine complex. Its members are also genetically more closely related to each other than falcons in other species complexes (see Hobbys, Merlins) (Wink et al. 2004, 2010, Nittinger et al. 2005, 2007). However, they are usually recognized as separate species. Interestingly, the Australian Black Falcon (F. subniger) is a member of the Hierofalcons. It apparently represents the group of large falcons in Australia.

The Prairie Falcon (F. mexicanus), formerly counted among the Hierofalcons, forms a sister taxon to the Peregrine - Hierofalco clade similar to the Grey Falcon (F. hypoleucos).

The kestrel group forms a monophylum with many species (Common Kestrel, Australian Kestrel, Madagascar Kestrel, Seychelles Falcon, Mauritius Falcon, Greater Kestrel, Fox Kestrel and Lesser Kestrel). The American Kestrels (F. sparverius) behave like kestrels, but they fall basal in the family trees and outside the "kestrel" group from the Old World.

Also Hobbys and their relatives fall into a clearly defined monophylum with Australian and African Hobbys, Sooty Falcons and Eleonora's Falcons. Depending on the calculation, the Orange-breasted Falcon ( $F$. deiroleucus) also falls into this group.

The Red-footed Falcon (F. vespertinus) is closely related to the Amur Falcon (F. amurensis); both species breed in Eurasia and winter in sub-Saharan Africa.

The Merlin (F. columbarius) is subdivided into several subspecies that are genetically highly differentiated and may have already reached species status.

The Red-headed Falcons F. chiquera form a monophylum that can be divided into three species F. horsbrughi, F. ruficollis and F. chiquera due to their distribution (India or Africa).

The African Grey Falcons (F. ardosiacus) and Dickinson's Kestrels (F. dickinsoni) are grouped as sister species.

The phylogenetic position of some Old World, New World and Australian species is unclear (i.e. not supported by significant bootstrap values); they do not form monophyla. 


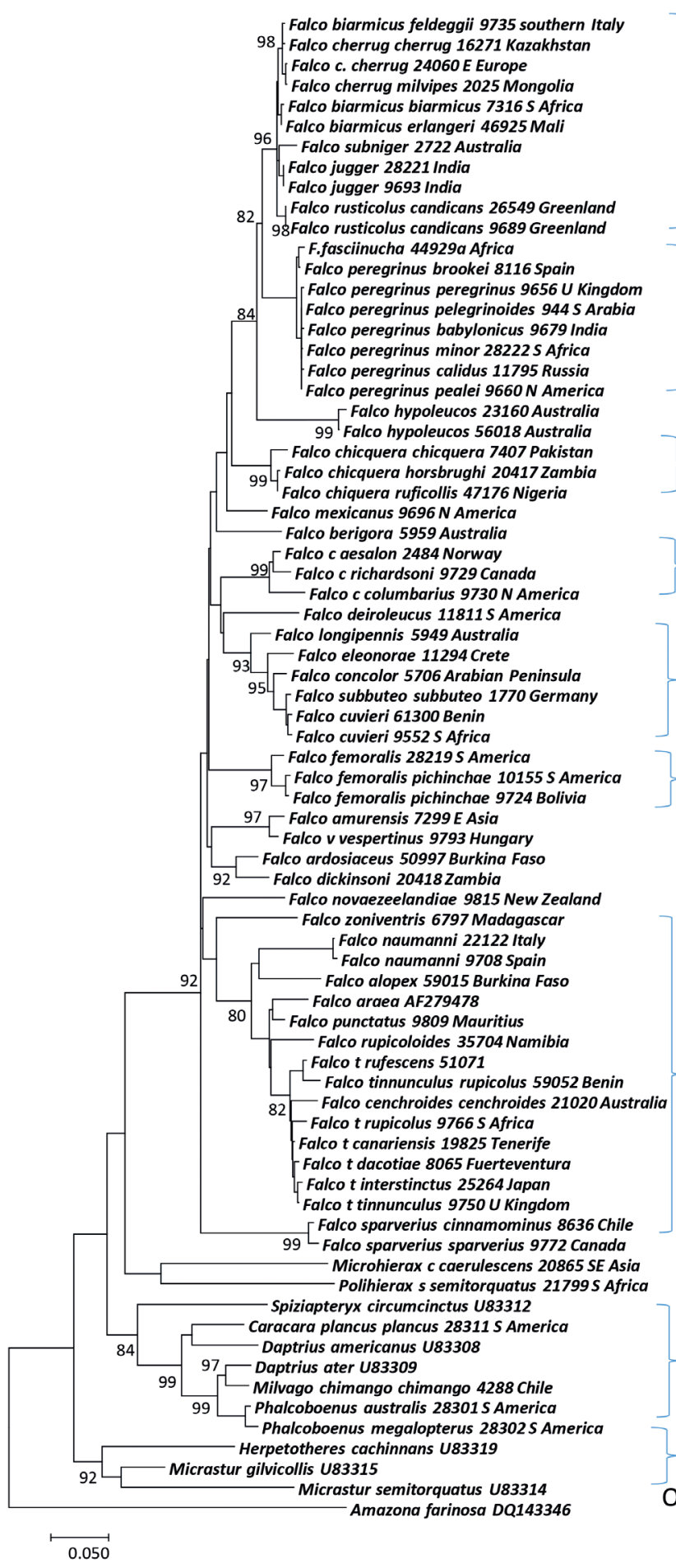

\section{Hierofalcons}

Peregrine F.

Grey Falcon

Red-headed F. Prairie Falcon

Merlins

Hobby Falcons

T FALCONINI

Aplomado F.

Red-footed F.

\section{Kestrels}

Falconet/Pygmy F.

\section{Caracaras}

Forest Falcons
T POLYBORINI 
Figure 2. Molecular phylogenetic analysis of falcons based on DNA sequences of the cytochrome $b$ gene by Maximum Likelihood method. The evolutionary history was inferred by using the Maximum Likelihood method based on the General Time Reversible model. The tree with the highest log likelihood (-11683.84) is shown. The percentage of trees in which the associated taxa clustered together is shown next to the branches. Initial tree(s) for the heuristic search were obtained automatically by applying Neighbor-Join and BioNJ algorithms to a matrix of pairwise distances estimated using the Maximum Composite Likelihood (MCL) approach, and then selecting the topology with superior log likelihood value. A discrete Gamma distribution was used to model evolutionary rate differences among sites ( 5 categories $(+G$, parameter $=1.0640)$ ). The rate variation model allowed for some sites to be evolutionarily invariable ([+1], $41.68 \%$ sites). The tree is drawn to scale, with branch lengths measured in the number of substitutions per site. The analysis involved 74 nucleotide sequences. Codon positions included were $1^{\text {st }}+2^{\text {nd }}+3^{\text {rd }}+$ Noncoding. There were a total of 1143 positions in the final dataset. Evolutionary analyses were conducted in MEGA7 (Kumar et al. 2016)

2. ábra A sólymok molekuláris filogenetikai elemzése a citokróm-b gén szekvenciája alapján. A csoport evolúciós történetisége a GTR modell alapján, maximum likelihood módszerrel lett meghatározva. Az ábrán a legmagasabb log-likelihood értékkel $(-11683,84)$ rendelkező fa látható. Az ágakon található számok annak a százalékos arányát mutatják, hogy az egyes taxonok milyen mértékben kerültek ugyanabba a pozícióba a különböző fákon. A távolságmátrixon alkalmazott maximális összetett likelihood (Maximum Composite Likelihood - MCL) képezte annak a heurisztikus keresésnek az alapját, mely Neighbor-Join és BioNJ algoritmusok alapján határozta meg a kiindulási fát/fákat, kiválasztva azt a topológiát, amelyik a legmagasabb log-likelihood értéket kapta. A bázisokban bekövetkező változások evolúciós frekvenciájának becslésére egy diszkrét Gamma-eloszlást feltételező modell szolgált ( 5 kategória (+G, paraméter $=1,0640)$ ). Egyes pozíciók változatlanságát egy újabb modell biztosította $([+I], 41,68 \%)$. A kapott fa ághosszai az egyes pozíciókban bekövetkező változások számával arányosan skálázottak. Ebben az elemzésben 74 nukleotid szekvencia szerepelt. Első+második+harmadik és nem kódoló kodon helyek lettek megkülönböztetve. A végső adatbázisban összesen 1143 pozíció szerepelt. Az elemzések a MEGA7 programban készültek (Kumar et al. 2016)

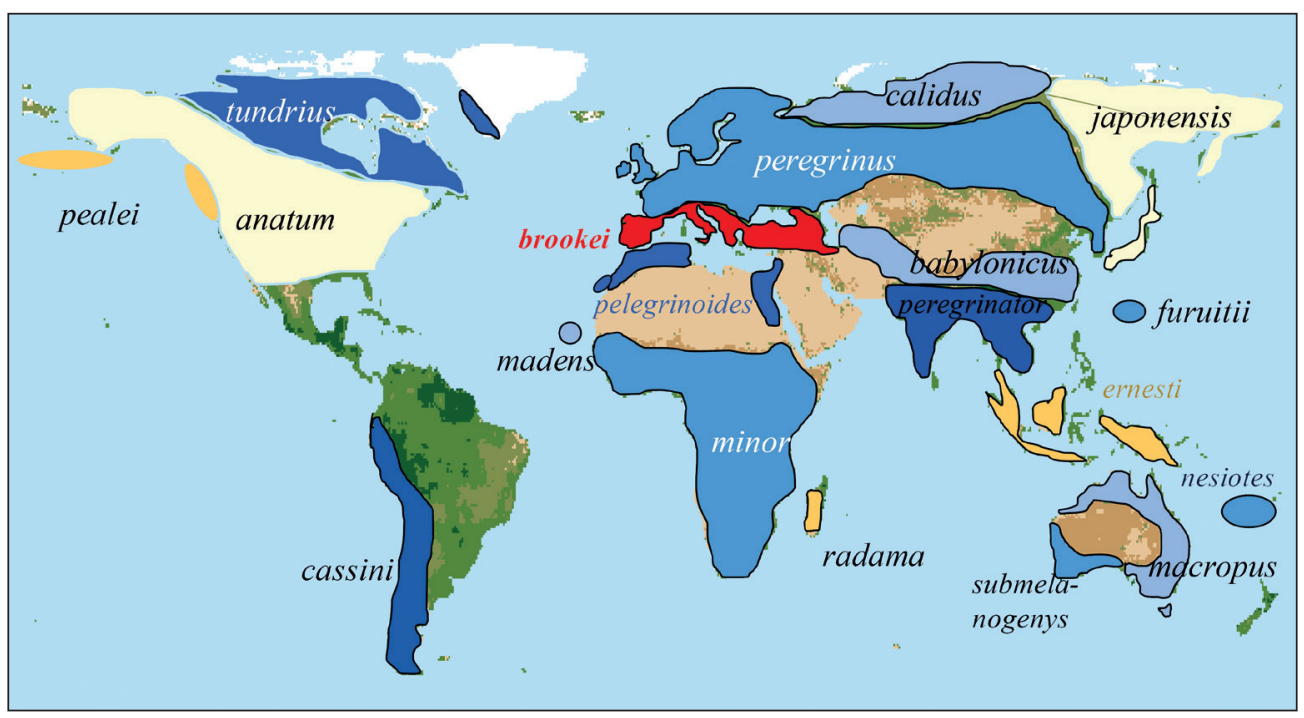

Figure 3. Distribution of the subspecies of the Peregrine Falcon

3. ábra A vándorsólyom alfajok földrajzi eloszlása 


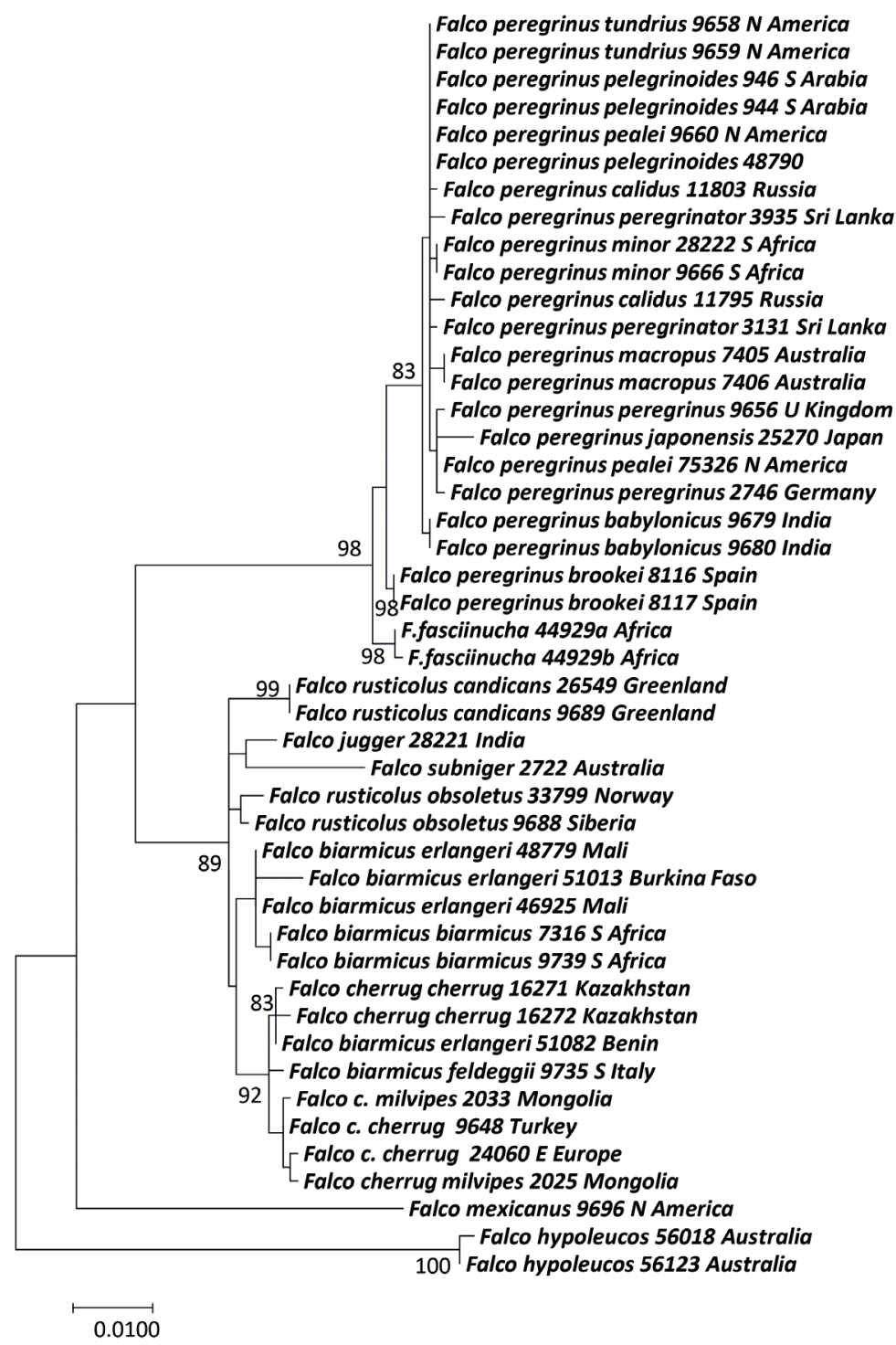

Peregrine Falcons

Taita Falcon

Hierofalcons

Prairie Falcon Grey Falcon

Figure 4. Molecular phylogenetic analysis of peregrine and Hierofalcons by Maximum Likelihood method. (Details as in Figure 2)

4. ábra A vándorsólyom és a Hierofalco alnemzetség molekuláris filogenetikai elemzése maximum likelihood módszerrel. (Részleteket lásd: 2. ábra)

\section{Systematics and phylogeography of Peregrine Falcons}

The Peregrine Falcon (F. peregrinus) is one of the few species of birds of prey with a cosmopolitan distribution. Presumably, many distribution areas of the Northern Hemisphere have only been populated after the end of the last glaciation period; thus the Peregrine Falcons 
form young populations in geological terms. A total of 16 to 19 subspecies are distinguished with differing distribution areas (Figure 3). These subspecies were defined due to differences in size, coloration and distribution, albeit obvious clinal patterns. When interpreting the distribution map, it is important to note that wide contact zones must exist between the defined subspecies in which natural mixing should take place. Furthermore, it is possible that the existing subspecies and local populations are mixed with Peregrine Falcons of other genetic origin, as genetically not clearly defined Peregrines have been released in many places in North America and Europe as part of reintroduction projects.

We have succeeded in genetically characterizing 11 subspecies of the Peregrine Falcon by sequencing their cytochrome b gene. As shown in Figure 4, all Peregrine Falcon subspecies are closely related. The genetic distances within the subspecies range between 0.01 and $0.8 \%$, indicating differentiation within the last 5000 to 400000 years. Our findings are confirmed by Bell et al. (2014), whose genetic distances in the cyt-b gene within Peregrine Falcons were between 0.001 and $1 \%$.

Only a few well-defined subgroups can be identified (Figure 4): F. p. brookei from the Mediterranean clusters as a basal group and is one of the few clearly differentiated subspecies. F. p. macropus from Australia, babylonicus from SE Asia and minor from Africa presumably form their own phylogenetic lines. The peregrinus cluster includes all other subspecies of the Peregrine Falcon. Even the Barbary Falcon (F. p. pelegrinoides), which was previously considered a species of its own, does not differ more than the other peregrine subspecies, so it is appropriate to consider it as a subspecies of the Peregrine Falcon.

In addition to our studies, the phylogeny of Peregrine Falcons has also been investigated in two further research groups (White et al. 2013, Bell et al. 2014). Bell et al. (2014) investigated sequences of the cyt $b$ gene of 41 Peregrine Falcons and 11 subspecies. They identified 16 haplotypes, which do not show any correlation with distribution and subspecies status. They found, however, that the Taita Falcon (F. fasciinucha), which occurs in Africa, is closely related to the Peregrine Falcons, but suggest that it is probably a species of its own. This is also apparent in our data (Figure 2, 4). F. p. brookei also showed (as in our work) a haplotype different from the other Peregrine Falcons. White et al. (2013) analyzed the more variable control region of 219 Peregrine Falcons, which included 12 subspecies (but not brookei). The result corresponds to the data from Bell et al. (2014) and our data, and implies that the subspecies cannot be defined genetically unambiguously and that a strong gene flow has taken place and probably still takes place.

\section{Genetic classification of Peregrine Falcons in Germany}

We have identified the cytochrome b haplotypes of meanwhile more than 300 young Peregrine Falcons, which had hatched between 2000 and 2015 in southern Germany (especially Baden-Württemberg; few from Rhineland Palatinate, Hesse, North Rhine-Westphalia and eastern Germany). According to their distribution range, they should theoretically belong to the subspecies F. p. peregrinus. However, $62 \%$ of the studied Peregrine Falcons show the clearly recognizable mitochondrial haplotype of $F$. p. brookei, which should only 
occur in the Mediterranean region (Figures 2, 4). Since the mtDNA is inherited maternally, the mothers of the brookei falcon chicks must also have the brookei haplotype. These can be pure brookei or, alternatively, peregrinus $\times$ brookei hybrids. Since the brookei and peregrinus haplotypes are often found in neighboring nests, we have to assume that the population of Central Germany consists of a mixture of brookei $\times$ peregrinus throughout. Nevertheless, pure brookei and peregrinus individuals are also expected (Wink et al. 2010).

This hybridization hypothesis was supported by a first microsatellite analysis (Wink et al. 2010). Five alleles were detected in the microsatellite locus NVH fp89. AT12 and AT13 are alleles characteristic of pure brookei from the Mediterranean region; these alleles are not found in peregrines of northern Europe with the haplotype peregrinus. But peregrine falcons from the German brookei cluster also have these alleles. This means that we are able to detect brookei not only via the maternal mtDNA, but also via the biparentally inherited nuclear DNA. The allele AT6 is only found in peregrinus, but also in the German brookei haplotypes. Accordingly, they must be - at least in part - hybrids.

Probably similar contact zones exist between the other subspecies of the Peregrine; no clear demarcations are expected for subspecies in theory either.

\section{Where do the brookei haplotypes come from?}

It would be naive to assume that there is a strict geographical separation of the two subspecies peregrinus and brookei. A more or less large contact zone would also theoretically be expected. Our current data indicates that the whole of Central Europe is such a contact zone. By examining almost 60 Peregrine Falcon skins from different museums from the period before 1960, we were able to establish that a contact zone with brookei haplotypes already existed before the population collapse (Rockenbauch 1998, 2002) and release measures in Central Europe; 42 peregrinus haplotypes were found in addition to 17 brookei haplotypes (Table 1). Compared to the current situation, the share of the brookei haplotype before the collapse of the Peregrine Falcon's population was lower than today, after recovery of stocks and reintroduction measures.

Already in the 1950s, German falconers dealt with the challenge of captive Peregrine breeding. Inspired by the success of the Peregrine breeders and reintroduction programs in the USA, breeding programs were initiated in Germany and between 1977 and 2010 a total of 1099 Peregrine Falcons were released in Germany (C. Saar, pers. comm.). Of 31 blood samples of breeding falcons provided by Prof. Dr. C. Saar, 29 carried the brookei haplotype. These falcons are descended from Peregrine Falcons from Scotland, which theoretically belong to the subspecies peregrinus. Our data indicate that brookei haplotypes are also found in the UK and the contact zone is even larger than expected. Therefore, it cannot be completely ruled out that the brookei haplotypes present in northern and eastern Germany are also descended from reintroduced falcons. The high proportion of brookei haplotypes in southern Germany, where no peregrine falcons have been released, indicates that a natural mixed population occurs here. 
Table 1. Haplotypes of Peregrine Falcons from Germany, which were sampled between 2000 and 2015 and of Peregrine Falcons from museum collections collected before 1960

1. táblázat A németországi vándorsólymok haplotípusai 2000 és 2015 közötti mintákból, valamint 1960 előtti múzeumi gyűjteményekből

\begin{tabular}{|l|c|c|}
\hline \multicolumn{1}{|c|}{ Region } & $\begin{array}{c}\text { Falcons with brookei } \\
\text { haplotype }\end{array}$ & $\begin{array}{c}\text { Falcons with peregrinus } \\
\text { haplotype }\end{array}$ \\
\hline $\mathbf{2 0 0 0 - 2 0 1 5}$ & 113 & 80 \\
\hline Baden-Württemberg & 5 & 7 \\
\hline Rhineland-Palatinate & 5 & 0 \\
\hline Nordrhein Westfahlen & 2 & 0 \\
\hline Hesse, Bavaria & 0 & 4 \\
\hline Niedersachsen & 48 & 18 \\
\hline East Germany & 17 & 6 \\
\hline Switzerland & $\mathbf{1 9 0}(\mathbf{6 2 \% )}$ & $\mathbf{1 1 5}$ (38\%) \\
\hline Total & & 4 \\
\hline Before 1960 & 4 & 7 \\
\hline Baden-Württemberg & 9 & 21 \\
\hline Baveria & 1 & 10 \\
\hline Saxony & 3 & $\mathbf{4 2 ~ ( 7 1 \% )}$ \\
\hline Norway & $\mathbf{1 7}(\mathbf{2 9 \% )}$ & \\
\hline Total & & \\
\hline
\end{tabular}

It was speculated that the Peregrine Falcons, which today populate more and more buildings, would be descendants of the reintroduced falcons. Since the brookei haplotypes of our study originate in part from building breeders from southern Germany, where no reintroduction or immigrants took place, it seems to be an ecological adaptation to urban life, similar to the way we know it from Blackbird, Wood Pigeon or Goshawk.

In conclusion; for the Peregrine Falcon a natural mixture between the subspecies is widespread phenomenon, which is also supported by the results of White et al. (2013) and Bell et al. (2014).

\section{Outlook}

The Peregrine Falcon seems to be one of the young species that only differentiated within the last 200,000 years during cycles of glaciation and adapted to different habitats and biomes. Variations in size and coloring are therefore to be seen as adaptive characters and as adaptations to the different environments. Since a strong mixing of haplotypes can be demonstrated, a systematic differentiation into clearly defined subspecies (except for $F$. $p$. brookei) must be regarded with some caution. It should not be forgotten, that the differentiation and global spread of modern man (Homo sapiens) also follows a similar pattern without genetically definable subspecies. 


\section{Acknowledgements}

Ms. H. Sauer-Gürth, S. Übbing and various trainees were responsible for the DNA isolation, PCR and DNA sequencing of the falcons that were included in this study. Samples were thankfully received by W. Bednarek, B. Clark, H. Brünning, M. Heidenreich, G. Ehlers, N. Baron, W. Scharlau, M. Pomarol, H. Prehn, P. Gaucher, R. Pfeffer, D. Schmidl, O. Hatzofe, D. Bird, C. Jones, M. Stubbe, H. Döttlinger, W. Grummt, J. J. Negro, D. Ristow, D. Peppler, I. E. Witt, S. Ostrowski, A. Stephenson, D. Ellis, U. Höfle, J. Olsen, R. Kenward, N. Fox, T. Osborne, A. Stephenson, C. Saar, N. Nowka, D. Schodde, H. Hepp, H. Schmid, M. Neuhaus, G. Kleinstäuber, G. Nikolaus and many AGW members. Museum skins could be sampled in the following museums: Zoologische Staatssammlung München, Naturhistorisches Museum Basel, Senckenberg Museum für Naturkunde Görlitz, Senckenberg Museum für Naturkunde Dresden, Natural History Museum Oslo, and Naturmuseum Solothurn.

\section{References}

Bell, D. A., Griffiths, C. S., Caballero, I. C., Hartley, R. R. \& Lawson, R. H. 2014. Genetic evidence for global dispersal in the Peregrine Falcon (Falco peregrinus) and affinity with the Taita Falcon (Falco fasciinucha). Journal of Raptor Research 48: 44-53. DOI: 10.3356/JRR-12-12.1

del Hoyo, J. \& Collar, N. J. 2014. HBW and BirdLife International Illustrated Checklist of the Birds of the World, Vol. 1. Non-passerines. - Lynx Edition, Barcelona

del Hoyo, J., Elliott, A. \& Sargatal, J. 1994. Handbook of the birds of the world, Vol. 2. - Lynx Edition, Barcelona

Hackett, S. J., Kimball, R. T., Reddy, S., Bowie, R. C. K., Braun, E. L., Braun, M. J., Chojnowski, J. L., Cox, W. A., Han, K-L., Harshman, J., Huddleston, C. J., Marks, B. D., Miglia, K. J. Moore, W. S., Sheldon, F. H., Steadman, D. W., Witt, C. C. \& Yuri, T. 2008. A phylogenomic study of birds reveals their evolutionary history. - Science 320: 1763-1768. DOI: 10.1126/science.1157704

Kraus, R. H. \& Wink, M. 2015. Avian genomics: fledging into the wild! - Journal of Ornithology 56: 851-865. DOI 10.1007/s10336-015-1253-y

Kumar, S., Stecher, G. \& Tamura, K. 2016. MEGA7: Molecular Evolutionary Genetics Analysis version 7.0 for bigger datasets. - Molecular Biology and Evolution 33: 1870-1874. DOI: 10.1093/molbev/msw054

Nittinger, F., Haring, E., Pinsker, W., Wink, M. \& Gamauf, A. 2005. Out of Africa: phylogenetic relationships between Falco biarmicus and the other Hierofalcons (Aves: Falconidae). - Journal of Zoological Systematics and Evolutionary Research 43: 321-331. DOI: 10.1111/j.1439-0469.2005.00326.x

Nittinger, F., Gamauf, A., Pinsker, W., Wink, M. \& Haring, E. 2007. Phylogeography and population structure of the Saker Falcon (Falco cherrug) and the influence of hybridization: mitochondrial and microsatellite data. Molecular Ecology 16: 1497-1517. DOI: 10.1111/j.1365-294X.2007.03245.x

Prum, R. O., Berv, J. S., Domburg, A., Field, D. J., Townsend, J. P., Lemmon, E. M. \& Lemmon, A. R. 2015. A comprehensive phylogeny of birds (Aves) using targeted next-generation DNA sequencing. - Nature 526: 568-573. DOI: 10.1038/nature15697

Rockenbauch, D. 1998. Der Wanderfalke in Deutschland und umliegenden Gebieten [Peregrine Falcons in Germany and neighboring countries]. Bd 1. - C. Hölzinger, Ludwigsburg (in German)

Rockenbauch, D. 2002. Der Wanderfalke in Deutschland und umliegenden Gebieten [Peregrine Falcons in Germany and neighboring countries]. Bd 2. - C. Hölzinger, Ludwigsburg (in German)

Seibold, I., Helbig, A. \& Wink, M. 1993. Molecular systematics of falcons (family Falconidae). - Naturwissenschaften 80: 87-90.

Sibley, C. G. \& Monroe, B. L. 1990. Distribution and Taxonomy of Birds of the World. - Yale University Press, New Haven \& London

Storch, V., Welsch, U. \& Wink, M. 2013. Evolutionsbiologie. $3^{\text {rd }}$ ed. - Springer-Verlag, Heidelberg

Suh, A., Paus, M., Kiefmann, M., Churakov, G., Franke, F., Brosius, J., Kriegs, J. \& Schmitz, J. 2011. Mesozoic retroposons reveal parrots as the closest living relatives of passerine birds. - Nature Communications 2. Article number 443. DOI: $10.1038 /$ ncomms 1448 
Weick, F. 1980. Die Greifvögel der Welt [Raptors of the world]. - P. Parey, Hamburg (in German)

White, C. M., Sonsthagen, S. A., Sage, G. K., Anderson, C. \& Talbot, S. L. 2013. Genetic relationships among some subspecies of the Peregrine Falcon (Falco peregrinus L.), inferred from mitocondrial DNA control-region sequences. - The Auk 130: 78-87. DOI: 10.1525/auk.2012.11173

Wink, M. 1995. Phylogeny of Old and New World vultures (Aves: Accipitridae and Cathartidae) inferred from nucleotide sequences of the mitochondrial cytochrome b gene. - Zeitschrift für Naturforschung 50c: 868-882. DOI: 10.1515/znc-1995-11-1220

Wink, M. 2000. Advances in DNA studies of diurnal and nocturnal raptors. - In: Chancellor, R. D. \& Meyburg, B-U. (eds.) Raptors at Risk. - WWGBP/Hancock House, pp. 831-844.

Wink, M. 2012. Evolution und Phylogenie der Vögel [Evolution and phylogeny of birds]. - Taxonomische Konsequenzen. - Vogelwarte 49: 17-24. (in German)

Wink, M. 2013. Ornithologie für Einsteiger [Ornithology for beginners]. - Springer-Spektrum, Heidelberg (in German)

Wink, M. 2015. Der erste phylogenomische Stammbaum der Vögel [A first phylogenomic avian tree of life]. Vogelwarte 53: 45-50. (in German)

Wink, M., Döttlinger, H., Nicholls, N. \& Sauer-Gürth, H. 2000. Phylogenetic relationships between Black Shaheen (Falco peregrinus peregrinator), Red-naped Shaheen (F. pelegrinoides babylonicus) and Peregrines $(F$. peregrinus). - In: Chancellor, R. D. \& Meyburg, B-U. (eds.) Raptors at Risk. - WWGBP/Hancock House, pp. 853-857.

Wink, M., El-Sayed, A-A. \& Gonzalez, J. 2010. Fortschritte in Erforschung der Phylogenie der Greifvögel und der Falken [Progress in phylogeny studies of raptors and owls]. - 50 Jahre Orden Deutscher Falkoniere, pp. 22-28. (in German)

Wink, M., Heidrich, P. \& Fentzloff, C. 1996. A mtDNA phylogeny of sea eagles (genus Haliaeetus) based on nucleotide sequences of the cytochrome b gene. - Biochemical Systematics and Ecology 24(7-8): 783-791. DOI: 10.1016/S0305-1978(96)00049-X

Wink, M. \& Ristow, D. 2000. Biology and molecular genetics of Eleonora's Falcon (Falco eleonorae), a colonial raptor of Mediterranean islands. - In: Chancellor, R. D. \& Meyburg, B-U. (eds.) Raptors at Risk. - WWGBP/Hancock House, pp. 653-668.

Wink, M. \& Sauer-Gürth, H. 2000. Advances in the molecular systematics of African raptors. - In: Chancellor, R. D. \& Meyburg, B.-U. (eds.) Raptors at Risk. - WWGBP/Hancock House, pp. 135-147.

Wink, M. \& Sauer-Gürth, H. 2004. Phylogenetic relationships in diurnal raptors based on nucleotide sequences of mitochondrial and nuclear marker genes. - In: Chancellor, R. D. \& Meyburg, B-U. (eds.) Raptors at Risk. - WWGBP, Berlin, pp. 483-498.

Wink, M., Sauer-Gürth, H., Ellis, D. \& Kenward, R. 2004. Phylogenetic relationships in the Hierofalco complex (Saker-, Gyr-, Lanner-, Laggar Falcon). - In: Chancellor, R. D. \& Meyburg, B-U. (eds.) Raptors at Risk. WWGBP, Berlin, pp. 499-504.

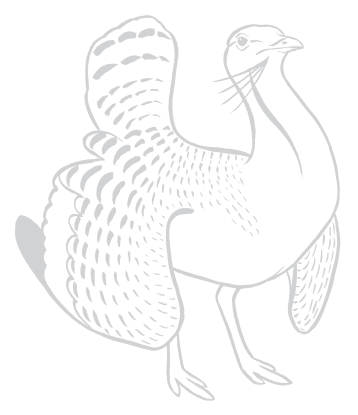

